\title{
Personnel Development in Chinese Innovation-Active Companies
}

\author{
Elena Zavyalova \\ Head of Organizational Behavior and HR Management Department, zavyalova@gsom.pu.ru
}

Artem Alsufyev

Assistant Professor of Organizational Behavior and HR Management Department, E-mail: alsufyev@gsom.pu.ru

School of Management of the St. Petersburg University, 3 Volkhovskiy Lane, St. Petersburg 199004, Russian Federation

Inna Krakovetskaya

Associate Professor of Strategic Management and Marking Department, inna_krakov@mail.ru

National Research Tomsk State University, 36 Lenina Str., 634050, Tomsk, Russian Federation

\author{
Wan Lijun \\ Head, sitlily@aliyun.com
}

Chinese-Russian Institute at the Shenyang Polythechnical University, 6 Nanpingzhong Rd Hunnan New District of Shenyang City, Liaoning Province, China

Jessica Li

Associate Professor, Education Policy, Organization and Leadership Department, jli2011@illinois.edu

University of Illinois Urbana Champaign, USA, 61820, Champaign, 354 Education Bldg 1310 S. Sixth St.

\begin{abstract}
$\mathrm{T}$ This article is devoted to an analysis of the mechanisms and tools that promote innovative activity at Chinese companies. We describe and evaluate the model of the Chinese innovation ecosystem with its major subsystems and their interconnections. Personnel training and development are considered an element of the subsystem "Education" within the innovation ecosystem, which serve as tools for the formation of human resources to ensure the transformation of the national economy into a global center of innovation. The authors analyze the main challenges connected with level of development of the environment and the socioeconomic institutions that may impede the effective management of human resources and the various practices for training personnel at innovative companies in China.The data analyzed for this empirical study on

training and development practices includes structured interviews at 60 medium and large innovative companies in China. Objective economic indicators of innovative activity were taken as measures. The analysis results allow one to identify four clusters of companies: "Innovators," "Leader in Training," "Stars," and "Lagging behind," describing the different company approaches to providing personnel training and development. Clusters vary in quantitative and qualitative indicators for personnel training and development processes, as well as economic indicators of innovation activity. The results prove that a relationship exists between approaches to personnel training and development and innovative activity results and suggest that training and development initiatives are effective tools for managing innovative companies.
\end{abstract}

\section{Keywords:}

innovation-active companies; the innovation ecosystem; state regulation of innovation activity; China; personnel training and development

Citation: Zavyalova E., Alsufyev A., Krakovetskaya I., Lijun W., Li J. (2018) Personnel Development in Chinese Innovation-Active Companies. Foresight and STI Governance, vol. 12, no 3, pp. 43-52. DOI: 10.17323/25002597.2018.3.43.52 
$\mathrm{T}$ he principles of designing and developing China's innovation system in the context of the national economy's transition "from imitating to independent innovation and development of high technologies" $[L i, 2010]$ were declared officially by the Chinese government. Chinese national innovation policy serves as the basis for the staged construction of such a system, which in turn is based upon Deng Xiaoping's theory of technological progress [Chang, 1996]. Leonov and Domnich [Leonov, Domnich, 2010] identify five stages of innovation policy implementation in China, each accomplishing important objectives for the national economy such as setting industry-specific priorities, creating conditions for generating new knowledge in breakthrough areas of science, developing mechanisms for their practical implementation, and so on. According to the "Strategic S\&T Development Plan 2006-2020" [Chinese Academy of Sciences, 2014], the country is expected to make a qualitative leap in terms of increasing the number of high-tech companies, the share of information and communication technologies (ICT) in national exports, and extending the range of telecommunication services' users (mobile and landline telephones, the internet, etc.). This has kicked off the fifth stage of implementing China's innovation policy, the goal of which is to achieve long-term sustainable development by modernizing all industries of the economy, and turning the country into an innovation leader.

The objectives set by the Chinese government required a review of the principles of human resources management. Successful modernization and technological upgrading of production facilities revealed a number of problems in this area, in particular, shortages of skilled professionals (specialists and managers alike), the lack of an overall human resources management strategy, and competition between global and local businesses, state-owned and commercial companies, and Western and domestic business practices. It takes decades to acquire unique engineering and managerial competences and experience, which makes staff training and development for innovative activities a particularly relevant issue. Apart from the practical relevance, studying the existing approaches to dealing with it also has a theoretical dimension connected with conceptualizing human capital development in the corporate sector of emerging countries.

The objective of this paper is to analyze staff training practices of medium and large innovative Chinese companies in order to study their approaches to it, keeping in mind that such techniques are seen as components of the "Education" subsystem of the Chinese national innovation ecosystem, and are employed as human capital management tools to accomplish strategic objectives of the country's innovation-based development.

\section{The Emergence and Development of China's Innovation Ecosystem}

The first steps towards creating the national innovation system were taken by the Chinese authorities in 1975, when the course towards "openness" was announced. This process was officially declared to be completed in 2010. As a component, or a subsystem of the global system, the national innovation system in its turn exceeds the sum of its elements; a systemic approach is required to describe and model it [Chistiakova, 2007].

The "black box" model we have used in this study analyzes a system's inputs and outputs and allows one to describe the system in terms of how it transforms them. The classic black, grey, and white box schemes, in addition to analyzing systems through their inputs and outputs, also involve studying the actual mechanism that transforms the former (resources) into the latter (products) (see Figure 1). The main components of the Chinese innovation system, and their functions, are presented in Table 1. Each functional subsystem affects the overall national potential, and its innovation environment.

The "Education" subsystem plays a key role in stepping up the country's innovation-based development, since the national innovation ecosystem and all its components require highly skilled personnel with unique competences and professional experience sufficient to generate and disseminate innovations and create new technological paradigms.

\section{Government Regulation of Innovative Activities in China}

At the initiative of the Ministry of Science and Technology of the People's Republic of China, more than 1,500 business incubators were established in the country, providing comprehensive support to innovative and high-tech companies. Eighty thousand firms use the incubators' services every year. The ministry also administers a 3.5 billion yuan investment fund (about 440 million euros) to support innovative projects. According to the European Commission, in 2012 the Chinese Innovation Fund for Small Technology-Based Firms (InnoFund) provided subsidies in the amount of about 520 million euros [European Commission, 2015].

One of the mechanisms for providing indirect support to innovative Chinese businesses is a preferential taxation regime. For example, just in the first three quarters of 2015, Chinese innovative firms received tax breaks in the amount of 237.5 billion yuan ( $\$ 37.2$ billion) [Xinhua, 2015]. Also, the state helps companies to patent and license their designs. All innovations created on Chinese territory are recorded in special 


\section{Figure 1. Model of the Chinese National Innovation Ecosystem}

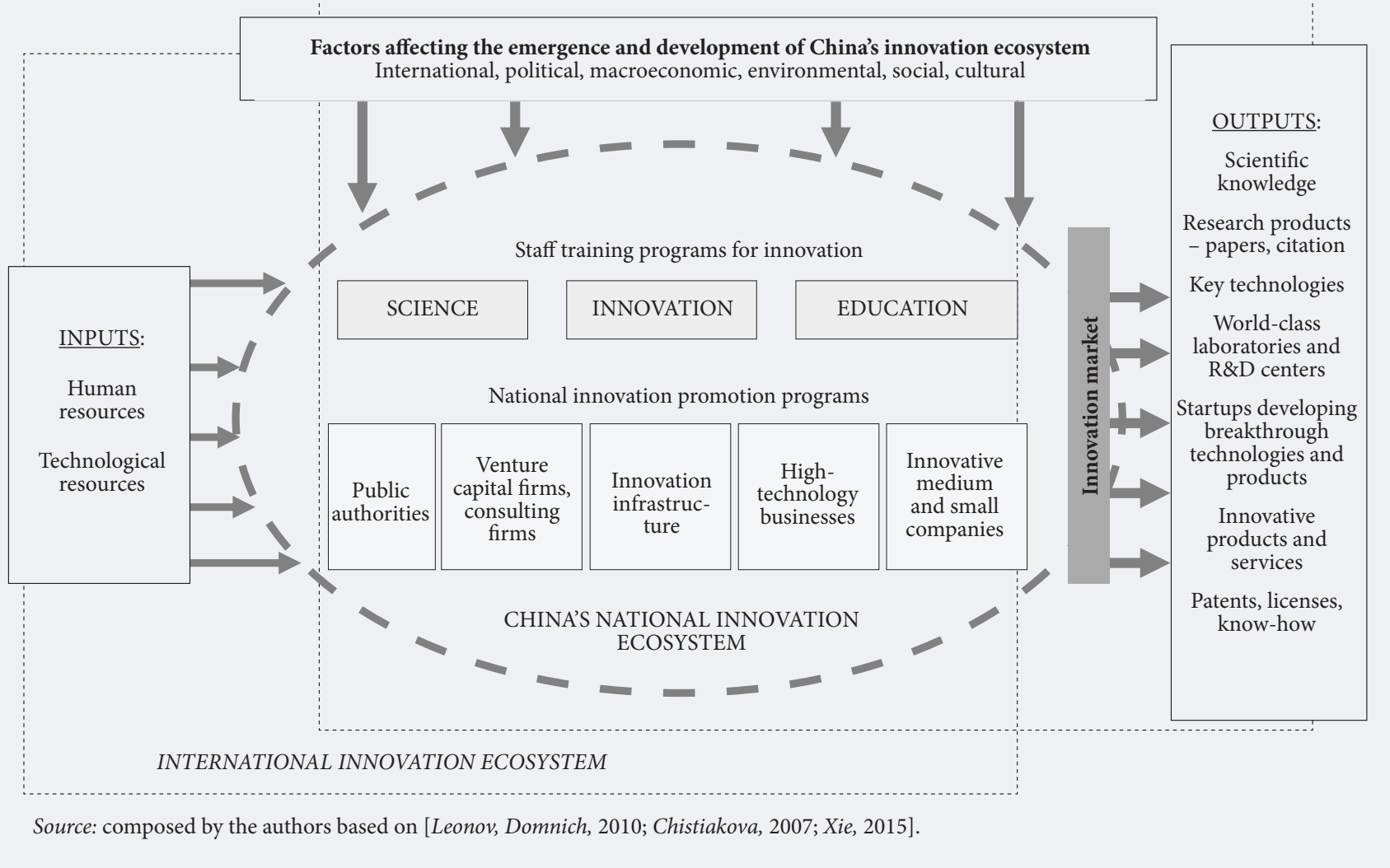

product catalogues, and subsequently receive preferential treatment when they take part in tenders or public procurement procedures.

The state controls all interaction between participants of various subsystems of the national innovation ecosystem, in particular those within the scope of the various national innovation support programs (Table 1).

\section{Approaches to Innovative Companies' Human Resources Management}

The re-orientation of Chinese businesses towards the application of knowledge and innovative technologies created demand for highly skilled professionals [Simon, Cao, 2009]. To address this issue, the Chinese government designed a set of measures to support and aid technological university graduates in job placement (Table 2). In particular, in the scope of the 1000 Talents Program, steps are being taken to repatriate more successful managers and scientists from abroad. Companies, especially innovative ones, also work on improving the quality of their human capital [Simon, Cao, 2009]. One of the tools they use for this purpose is improving their human resources management systems - an issue businesses used to pay insufficient attention to. The first labor code adopted in the country which strongly protects workers' rights serves as the mechanism regulating labor relations since 2008.

By the beginning of the $21^{\text {st }}$ century, companies were only starting to move on from the personnel management concept to the human resources management principle [Soltitskaya, Bo, 2005]. Personnel managers tended to have a rather low status, and their functions normally were administrative and based on control. However, innovative companies have always been somewhat different in this respect. A recent study of the correlation between the level of firms' R\&D activities and their personnel management practices identified the following practices: setting up cross-functional project groups; systematically arranging training events and workshops to upgrade employees' qualifications; sharing experiences with other companies in the industry; and providing financial incentives to encourage employees' participation in R\&D [Eriksson et al., 2014].

Certain authors point out China's national features as the reason for different approaches to managing human resources. The first such specific feature is connected with companies' ownership. Malcolm Warner [Warner, 2008] notes that state-owned companies in the country frequently bear the burden of 
Table 1. The Components of the Chinese Innovation System, and their Functions

\begin{tabular}{|c|c|}
\hline Subsystem & Function \\
\hline Public authorities & $\begin{array}{l}\text { - Government regulation and promotion of innovation activities in the country, directly and indirectly } \\
\text { - Funding research and development (R\&D) } \\
\text { - Development of legal basis for innovation activities } \\
\text { Development and modernization of innovation infrastructure }\end{array}$ \\
\hline $\mathrm{R} \& \mathrm{D}$ sector & $\begin{array}{l}\text { - Creating new knowledge and radical innovations } \\
\text { - Conducting R\&D in priority science and technology (S\&T) areas } \\
\text { - Training R\&D personnel }\end{array}$ \\
\hline $\begin{array}{l}\text { High-technology } \\
\text { businesses }\end{array}$ & $\begin{array}{l}\text { - Production of high-technology products and services } \\
\text { - Job creation } \\
\text { - Funding R\&D from their own sources } \\
\text { Integration of large companies, leading R\&D organizations, and universities }\end{array}$ \\
\hline $\begin{array}{l}\text { Small and medium } \\
\text { innovative businesses }\end{array}$ & $\begin{array}{l}\text { - Production of innovative products and services } \\
\text { - Job creation in the innovative business sector } \\
\text { - Funding R\&D from their own sources }\end{array}$ \\
\hline $\begin{array}{l}\text { Innovation } \\
\text { infrastructure }\end{array}$ & $\begin{array}{l}\text { - Commercialization of R\&D results } \\
\text { - Promoting creation of small research-intensive companies } \\
\text { - Pob creation }\end{array}$ \\
\hline Education sector & $\begin{array}{l}\text { - Training and upgrading personnel to create innovations } \\
\text { - Conducting basic and applied research at universities } \\
\text { - Achieving "critical mass" of talented people } \\
\text { - Promotion of innovative culture in the business environment } \\
\text { - Development of innovative education technologies } \\
\text { - Development of innovation infrastructure } \\
\text { - Increasing overall intelligence level of the population }\end{array}$ \\
\hline
\end{tabular}

the traditionally established personnel management practices [Child, David, 2001; Warner, 1996]. Quite natural for large, old enterprises, this organizational inertia comes at odds with the economic reforms aimed at encouraging companies in the non-public sector to promote the development of human capital [Ding, Akhtar, 2001].

Another feature is evident in the problems Chinese companies encounter when they try to apply Western human resources management standards. Values shared by the local staff include harmony and a complex system of informal connections - the so-called guanxi [Verburg et al., 1999]. Chinese workers are more inclined to accept their superior's opinion and obey rather than initiate change, so they would not disrupt the harmony at the company [Zhao, 1994]. In the context of unequal, hierarchic relations, changes at the workplace are seen as undermining stability [Hofstede, 1991]. This contradiction becomes particularly apparent when rewards and incentives programs are implemented [Sumelius, 2009]. Despite the higher compensation, Chinese citizens are not very keen on working for foreign companies: they do not like the high intensity of work, the rigid bureaucratic subordination, strict discipline, and lack of flexible working hours [Nyrovba, 2009]. There is no standing in for each other on a traditional Chinese team: areas of responsibility at companies are delineated so strictly that employees in the same division frequently have no idea what their colleagues who report to a different boss actually do. It is a Confucian tenet: to bring harmony into the world, everybody must do their job as best they can, and pay no heed to others. The sources of strict division of work responsibilities can be traced all the way back to the ancient institute of apprentices [Marchenko, 2013].

There is a version according to which human resources management systems in China may develop towards hybrid forms, including various combinations of local managerial features and Western or East Asian practices [Warner, 1996]. The authors of another study [Ding et al., 1997] come to a similar conclusion: they link the degree of integration of various approaches to human resources management to organizations' characteristics, and their chosen strategies for achieving competitive advantages.

\section{Staff Training at Chinese Companies}

Human resources management strategies and practices employed by innovative companies depend on their approach to staff training and development as tools to acquire more relevant competences. Very few companies have resources to design and implement staff training systems on their own. Following the Western example, the well-known Lenovo Group established its own corporate university - the Lenovo University. State-owned companies very much lag behind private firms in this area [Warner, 1993, 1996], which among other things is confirmed by the data published in a study of human resources management practices at various Chinese companies [Lu, Bjorkman, 1997]. Most of the studies stress that such training programs remain less than perfect [Lu, Bjorkman, 1997, 1998]; they are mostly focused on developing technical skills, as opposed to managerial competences [Child, 1996].

Training programs in technical and managerial skills are quite common in the corporate sector, but stateowned companies implement them much more rarely. Joint ventures typically provide training of both 


\section{Table 2. National Chinese S\&T and Innovative Activity Support Programs}

\begin{tabular}{|c|c|}
\hline Program & Brief description \\
\hline 863 Program & $\begin{array}{l}\text { A government program to promote S\&T research and development of high technologies; the goal is to } \\
\text { eliminate the country's dependency on high technology imports and to achieve breakthroughs in key } \\
\text { technology areas. A strategy for researching and developing high technologies was designed in the scope } \\
\text { of the program, along with a set of measures aimed at raising a new generation of personnel to work in the } \\
\text { high-technology sectors of the economy. }\end{array}$ \\
\hline 973 Program & $\begin{array}{l}\text { This is a national basic S\&T research plan which among other things envisages mobilizing research talent } \\
\text { to promote such areas as agriculture, energy, ICT, natural resources and environment, demography, and } \\
\text { health. The program makes provisions for training research personnel to conduct innovative research } \\
\text { in breakthrough areas, with the potential to contribute to the country's economic, social, and S\&T } \\
\text { development. }\end{array}$ \\
\hline Key Technologies Program & $\begin{array}{l}\text { This program is designed to support research aimed at achieving breakthroughs in developing key } \\
\text { technologies, technological modernization, restructuring traditional and promoting the emergence of new } \\
\text { industries to implement domestic innovation. The program allocates public funding to universities and } \\
\text { research institutes, whose productivity is assessed on the basis of their research results (i.e., publications } \\
\text { and patents). }\end{array}$ \\
\hline $\begin{array}{c}\text { Excellent Engineers Training } \\
\text { Program }\end{array}$ & $\begin{array}{l}\text { A project of the Ministry of Education of the People's Republic of China to implement medium- and long- } \\
\text { term programs for reforming the education system and providing support to Chinese talent in 2010-2020, } \\
\text { to improve the quality of enrolment, education, and training of talented engineers. }\end{array}$ \\
\hline $\begin{array}{l}\text { New Century Excellent } \\
\text { Talents }\end{array}$ & $\begin{array}{l}\text { The program's objective is to create a platform for training of and to provide support to research leaders } \\
\text { with large innovation potential. For this purpose, about } 1,000 \text { outstanding young scientists are annually } \\
\text { selected across the country, to receive subsequent support. }\end{array}$ \\
\hline Hundred Talents Program & $\begin{array}{l}\text { The program is aimed at encouraging talented professionals aged under } 45 \text { to come and work in China. } \\
\text { Subsidies are offered of up to } \$ 240,000 \text { per scientist, for a period of up to three years. The money can } \\
\text { be spent on funding research, paying researchers' rents and salaries. The program strives to deepen the } \\
\text { integration of the Chinese Academy of Sciences (CAS) into the global context. About } 81 \% \text { of the CAS } \\
\text { members, and } 54 \% \text { of the Chinese Academy of Engineering members are repatriated scientists. }\end{array}$ \\
\hline Thousand Talents Program & $\begin{array}{l}\text { The objective of the program is to encourage top-level foreign researchers to come and work in China on } \\
\text { a long-term basis (starting from three years), and fund their research. By the middle of 2012, 2,263 high- } \\
\text { level international scientists took part in the program. }\end{array}$ \\
\hline $\begin{array}{c}\text { Innovation } 2020 \text { Personnel } \\
\text { Development Strategy }\end{array}$ & $\begin{array}{l}\text { The implementation of this medium- to long-term strategy (2010-2020) is the responsibility of the CAS. } \\
\text { The objective is to train more than 3,000 young talented researchers in the S\&T area, and more than } \\
2,000 \text { innovation team leaders for industrial application of S\&T achievements. }\end{array}$ \\
\hline 211 Project and 985 Project & $\begin{array}{l}\text { The projects envisaged that leading Chinese universities would be included into the global top } 100 \text { by } \\
\text { the beginning of the } 21 \text { st century. Nine universities were initially selected to receive priority funding; } \\
\text { subsequently the list was extended. Now several elite Chinese research universities are indeed included } \\
\text { in the top } 100 \text { ranking, that is, they are becoming competitive in the global educational services market. }\end{array}$ \\
\hline
\end{tabular}

these types, with priority given to technical skills. A larger-scale study [Zhu, 1998] based on a sample comprising 440 enterprises of different ownership status in Shanghai revealed that joint ventures usually offer additional training to their staff, including technical and managerial skills. The author divided staff training and development objectives into three groups:

1. correcting employees' shortcomings, upgrading their technical knowledge and skills;

2. increasing employees' ability to adapt;

3. strengthening employees' loyalty.

The companies in the sample were asked to range each element in these three groups on a five-point scale in relation to the current and expected situation. Contrary to previous studies, this one's results revealed that state-owned companies offer more training programs than firms of other ownership do, and the training they offer is focused on developing professional skills needed to increase productivity. Technical training is seen as standard practice, while training in behavioral skills such as team work or interpersonal communication remains at low or moderate levels. Also, a modest amount of training aimed at increasing employees' understanding of the company's business and values is offered. Generally, all of the above tools are believed to be effective in terms of helping one to accomplish business objectives. Another Chinese study based on a sample of 156 companies with foreign participation revealed that training played an important role in accomplishing the following six objectives [Tang et al., 1996]:

1. advancing managers' administrative competencies;

2. increasing productivity;

3. extending the range of employees' skills;

4. increasing employees' readiness for technological innovations;

5. increasing adaptability to changing production processes;

6. strengthening employees' morale.

The authors of the study also noted that high labor turnover at foreign-owned companies hindered investments in staff training. Other studies made similar conclusions [Tsang, 1994; Ding, Akhtar, 2001]. 
An analysis of staff training's impact upon Chinese production companies' performance [Ng, Siu, 2004] shows that non-state companies see this tool as more important than state-owned firms do. Staff training is conducted to improve work relationships, deal with skill shortcomings, and develop necessary professional competences. State-owned companies give priority to technical skills, while non-state firms seem to be more interested in improving employees' relations and developing their communication skills. Expectations and actual results of training do not significantly vary between companies of different ownership status, while its perceived efficiency is equally high. Expenditures on staff training are directly connected to companies' performance. On the whole, the existing staff training programs in the Chinese corporate sector tend to be of hybrid nature, combining national personnel management traditions with Western approaches.

Strikingly different assessments of approaches to staff training, and of relevant techniques applied by Chinese companies, lead us to the main research question of this study: what are the specific features of staff training by innovative Chinese companies, in terms of its organization and content?

\section{Methodology and Sampling}

A qualitative, or descriptive, analysis of staff training and development practices applied by innovative Chinese companies (which are very different in terms of the numerous contextual and organizational characteristics) is not solely limited to revealing relevant causal relationships; it also implies studying the behavior of specific individual players. A variety of qualitative analyses, namely cluster analysis, was chosen for the purposes of this study. Data collected in the scope of the survey conducted by the Graduate School of Management of the St. Petersburg State University and the University of Illinois in 2011-2013 served as the empirical basis of the study. To assess the human capital development practices (including staff training), employees' efficiency, compensation, and career paths, members of the latter university applied special in-house developed tools [Bartlett et al., 2002], which subsequently have been used in other international surveys including in Russia [Ardichvili, Dirani, 2005]. The toolset comprises a series of structured interviews based on John Lawler's questionnaire [Lawler et al., 1995]; the answers are given using a seven-point Likert scale where scores 1 to 5 indicate the degree of the respondents' agreement with suggested statements $(1=$ totally disagree, $5=$ completely agree); $6=$ not applicable to the company, and 7 = cannot say. Several questions were aimed at collecting data about the company (number of employees) and the respondent (position). The sample comprised 60 innovative Chinese firms selected using the methodology described in the Oslo Manual [OECD, Eurostat, 2005] which offers guidance for collecting and interpreting innovation data. Due to the difficulties with identifying such activities in China, the "snowball" technique was used to collect relevant data.

Cluster analysis is well suited for building classifications, i.e. dividing the initial array of observed objects into classes. Their characteristics allow one to assess groups' similarities and differences, including oneto-one comparisons. Classifying observations in the sample implies distributing the objects into classes in such a way that the similarities within each class were stronger than those between objects in different classes. In other words, cluster (hierarchical) analysis is a statistical technique for organizing objects into comparatively homogenous groups (or clusters) on the basis of their one-to-one comparison using certain criteria set in advance. In our case, seven staff training and development practices applied by innovative Chinese companies served as such criteria. The survey was conducted among two types of respondents: managers and professionals; their reactions to the following statements were used as variables:

1. "Our company spends significant amounts of money on staff training and development" (training expenditures);

2. "We see training expenditures more like long-term investments rather than production costs" (training as investment)

3. "Training is primarily directed at giving workers more and broader knowledge, as opposed to training them for their current jobs" (broad approach to training)

4. "Our company pays considerable attention to training to help employees acquire various skills, so they would be able to stand in for each other if need be" (cross-functional training)

5. "Our company's employees frequently work in autonomous groups" (team work)

6. "New employees undergo serious training aimed at learning company values and traditions" (adaptation programmes)

7. "Our training is aimed at improving employees' interpersonal communication skills" (communication training).

Innovative activity indicators applied in our study included the following variables: share of innovations in total volume of shipped products; share of innovations in total exports; number of patents received in two previous years; number of patent applications submitted during the same period. The share of innovative products was measured using a five-point Likert scale, the patents and patent applications indicators - using a binary scale.

The cluster analysis of innovative Chinese companies allowed us to group them on the basis of similarity of their staff training and development practices. Comparing the mean values helped us identify certain 


\section{Table 3. Size of Chinese Companies Included in the Sample (Number of Employees)}

\begin{tabular}{|c|c|c|}
\hline Number of employees & Number of observations & Share in the sample (\%) \\
\hline $100-249$ & 14 & 23.3 \\
\hline $250-499$ & 5 & 8.3 \\
\hline $500-749$ & 22 & 36.7 \\
\hline $750-1500$ & 19 & 31.7 \\
\hline Bcero & 60 & 100.0 \\
\hline Source: composed by the authors.
\end{tabular}

patterns in the groups regarding the share of innovations in the total output and exports, the number of patents and patent applications, which can be interpreted as business behavior patterns.

The survey's respondents were top managers and members of HR departments of medium (100-500 employees) and large (>500 employees) companies. The distribution of companies in the sample by number of employees is presented in Table 3.

\section{Discussion of Results}

The results of the analysis include the mean values for staff training and development practices applied by companies in each of the four constructed clusters (Table 4). Since the variables were measured using a five-point Likert scale, a mean value above three allows one to describe a staff training practice as actively used, and a value below three - as rarely applied.

The mean values of companies' innovation activity indicators for each of the four clusters are presented in Table 5 .

The cluster analysis of innovative Chinese companies' staff training and development practices allowed us to break the companies down into the following four groups:

1) Innovators (comprises two firms): the highest innovative activity indicators, and moderate staff training and development expenditures;

2) Staff training leaders (the largest group, comprises 52 companies): lower innovative activity indicators but high staff training and development figures;

3) Laggers (comprises five companies): low staff training and development and innovative activity indicators alike;

4) Stars (a single firm): top staff training and development indicators, with no data available about the level of innovative activity.

The largest cluster ( 52 firms) has average innovative activity values, both in terms of products and patents. These companies invest serious money in staff training and development (the mean indicator value is 3.81) and see it as long-term investments aimed at extending the range of employees' competences, cross-functional training, adaptation, and the development of communication and team work skills. Companies in this group can be seen as staff training and development leaders of Chinese businesses. Their predominance in our sample allows us to profile a typical national innovative firm as follows: an average level of innovative activity against the background of large-scale staff training and development programs.

Table 4. Staff Training and Development by Innovative Chinese Companies (mean values of assessments made using a five-point Likert scale)

\begin{tabular}{|c|c|c|c|c|}
\hline \multirow{2}{*}{ Parameters } & \multicolumn{4}{|c|}{ Company clusters } \\
\hline & Innovators & Staff training leaders & Laggers & Stars \\
\hline Number of observations & 2 & 52 & 5 & 1 \\
\hline Training expenditures & 2.75 & 3.81 & 2.20 & 5.00 \\
\hline Training as an investment & 1.00 & 1.88 & 3.70 & 5.00 \\
\hline Broad approach to training & 2.50 & 3.26 & 3.10 & 5.00 \\
\hline Cross-functional training & 4.25 & 3.98 & 2.90 & 5.00 \\
\hline Team work & 4.00 & 3.14 & 2.00 & - \\
\hline Adaptation programs & 2.25 & 4.10 & 3.40 & 5.00 \\
\hline Communication training & 4.00 & 3.07 & 3.70 & 5.00 \\
\hline
\end{tabular}


Table 5. Innovative Activities of Chinese Companies (mean values of assessments made using a five-point Likert scale)

\begin{tabular}{|c|c|c|c|c|}
\hline \multirow{2}{*}{ Parameters } & \multicolumn{4}{|c|}{ Company clusters } \\
\hline & Innovators & Staff training leaders & Laggers & Stars \\
\hline Number of observations & 2 & 52 & 5 & 1 \\
\hline Share of innovative products & 3.50 & 2.87 & 2.00 & - \\
\hline Share of innovative products in exports & 3.00 & 1.89 & 1.00 & - \\
\hline Number of patents & 2.00 & 1.85 & 1.33 & - \\
\hline Number of patent applications & 2.00 & 1.82 & 1.00 & - \\
\hline Average value for innovative products & 3.25 & 2.41 & 1.67 & - \\
\hline Average value for patents and patent applications & 2.00 & 1.83 & 1.17 & - \\
\hline
\end{tabular}

The second group is represented by just two examples of very high innovative activity, in terms of the share of innovative products (the mean value of 3.25) and patents (2.00) alike. The companies in this group are not inclined to spend a lot on staff training and development (the average value is 2.75) since they do not see the long-term potential of such programs. The training programs they do implement are designed to enable workers to do their jobs better; no personnel adaptation courses are offered, but there is cross-functional training, and the development of communication and team work skills. In other words, Chinese innovators pay the least attention to staff training and development among all domestic companies, and the programs they do offer mostly provide cross-functional and team work training.

The third group (comprises 5 companies) displays the lowest innovative activity values and small staff training and development expenditures (the average value is 2.20), but these firms do see such costs as long-term investments. Companies in this group are interested in extending employees' knowledge and giving them cross-functional training; they offer adaptation and communication skills programs, but do not set up autonomous teams. These are the least innovative companies, but they make the biggest effort to develop their human capital - and tend to have problems with funding relevant programs.

The fourth group is limited to a single example displaying the highest staff training and development expenditures (the value is 5.00). Indicators for all training programs are seen as long-term investments are at the top level, while training areas include extending knowledge, cross-functional training, adaptation, and the development of communication skills. No data is available about the firm's innovative activities, so in effect the latter amount to just training programs.

\section{Conclusion}

To identify the specific features of staff training and development arrangements of innovative Chinese companies, keeping in mind the significant disparities in assessments of the approaches they apply, we conducted cluster analysis of 60 national companies. The relevant data was used to analyze links between staff training practices and the level of innovative activities. Most of the firms in the sample (52) funded various forms of staff training while displaying average innovative activity regardless of how it was measured (as share of innovative products or the number of patents). The two companies in the sample with the highest performance indicators offered only a limited range of staff training programs, and invested in this area moderately. Companies which had no resources to fund staff training programs despite being willing to do so, displayed the lowest innovative activity indicators. Unfortunately, the firm which has adopted the most solid approach to staff training and development did not provide data about its innovative activities, but what data we had was sufficient to suggest that investments in human capital development have a significant impact on the results of companies' innovative activities.

Summarizing the obtained results allows us to draw several important conclusions. The first concerns the development of staff training practices, and approaches to making relevant arrangements. As was noted in [Soltitskaya, Bo, 2005], human resources management in the Chinese corporate sector is in its infancy - at the transition stage from the administrative approach. The same applies to the staff training and development system. During the previous 12 years Chinese firms, including innovative ones, made significant progress both in terms of funding staff training programs and applying specific practices. The empirical study showed that "staff training leaders" invested significant resources in various forms of staff training and development, including cross-functional training, broad general training, team work, and adaptation and company values programs. All this helps the companies in this group achieve average innovative activity indicators for the sample.

The results of the study also reveal that existing staff training programs tend to take hybrid forms combining Chinese personnel management traditions with relevant Western approaches. Innovative domestic companies have largely overcome the legacy of guanxi tied to the Confucian values, which 
give priority to personal responsibility. In the scope of that archaic culture, workers are not expected to know what their colleagues do, and the scope for standing in for each other is extremely limited. Crossfunctional training practices are borrowed from the Western human resources management experience and are widely employed by innovative companies in countries with developed and emerging markets.

The transformation of innovative Chinese companies' approaches to staff training and retraining is taking place in the framework of the "Education" subsystem of the national innovation ecosystem. The state's close attention to relevant programs, their prioritization and implementation ultimately are embodied in the approaches and training techniques innovative firms apply to their human resources, and in the results of their activities. Further studies of staff training and development practices which promote the innovative activity of Chinese businesses should focus on analyzing experience of specific firms. This could help innovative players in other emerging markets build more efficient staff training systems.

The paper was supported with the grant "Human resources development and training as a factor affecting competitiveness of companies operating in emerging markets" (16.23.1842.2015) provided by the Graduate School of Management of the St. Petersburg State University.

\section{References}

Ardichvili A., Dirani K. (2005) Human Capital Practices of Russian Enterprises. Human Resource Development International, vol. 8, no 4, pp. 403-418.

Bartlett K. R., Lawler J. J., Bae J., Chen S., Wan D. (2002) Differences in International Human Resource Development Among Indigenous Firms and Multinational Affiliates in East and Southeast Asia. Human Resource Development Quarterly, vol. 13, no 4, pp. 383-405.

Chang M. (1996) The Thought of Deng Xiaoping. Communist and Post-Communist Studies, vol. 29, no 4, pp. 377-394.

Child J. (1996) Management issues in China, New York: Routledge.

Child J., David K.T. (2001) China's transition and its implications for international business. Journal of International Business Studies, vol. 32, no 1, pp. 5-21.

Chinese Academy of Sciences (2014) China’s Strategic Options for S\&T Development Toward 2020. Bulletin of the Chinese Academy of Sciences, vol. 28, no 1, pp. 107-113.

Chistyakova N.O. (2007) Regional'naya innovatsionnaya sistema: sushchnost', struktura, spetsifika [Regional innovation system: Essence, structure, specificity]. Innovatsii [Innovation], no 4, pp. 56-59 (in Russian).

Ding D., Fields D., Akhtar S. (1997) An empirical study of human resource management policies and practices in foreign-invested enterprises in China: The case of Shenzen Special Economic Zone. International Journal of Human Resource Management, vol. 8, no 5, pp. 595-613.

Ding D.Z., Akhtar S. (2001) The organizational choice of human resource management practices: A study of Chinese enterprises in three cities in the PRC. International Journal of Human Resource Management, vol. 12, no 6, pp. 946-964.

Eriksson T., Qin Z., Wang W. (2014) Firm-level Innovation Activity, Employee Turnover and HRM Practices Evidence from Chinese Firms (Economics Working Papers 2014-09), Aarhus: Aarhus University. Available at: http://econ.au.dk/fileadmin/site_files/filer_oekonomi/Working_Papers/Economics/2014/wp14_09.pdf, accessed on 01.11.2017.

European Commission (2015) Evolution of China's Innovation Performance: 2000-2013. Brussels: European Commission, Available at: https://ec.europa.eu/research/innovation-union/pdf/evolution_of_china_innovation_ performance.pdf, accessed on 01.11.2017.

Haour G., von Zedwitz M. (2016) Created in China: How China is becoming a global innovator, London: Bloomsbury Publishing.

Hofstede G. (1991) Cultures and organizations. Intercultural cooperation and its importance for survival. Software of the mind, London: McGraw-Hill.

Lawler J.J., Jain H., Ratnam C., Atmiyanandana V. (1995) Employment practices in developing countries: A comparison of India and Thailand. International Journal of Human Resource Management, vol. 6, no 2, pp. 319-346.

Leonov S.N., Domnich E.L. (2010) Gosudarstvennaya innovatsionnaya politika poreformennogo Kitaya: soderzhanie, periodizatsiya, masshtaby [State innovation policy of post-reform China: Content, periodization, scale]. Vestnik TOGU [Bulletin of the Pacific National University], vol. 2, no 17, pp. 168-176 (in Russian).

Li Y. (2010) Imitation to Innovation in China. The Role of Patents in Biotechnology and Pharmaceutical Industries, Cheltenham: Edward Elgar.

Lu Y., Bjorkman I. (1997) HRM practices in China-Western joint ventures: MNC standardization versus localization. International Journal of Human Resource Management, vol. 8, no 5, pp. 614-628.

Lu Y., Björkman I. (1998) Human resource management in international joint ventures in China. Journal of General Management, no 23, pp. 63-79.

Marchenko V. (2013) Kak upravlyayut personalom v Kitae: osobennosti kitaiskogo mentaliteta [How the personnel in China are managed: The characteristics of the Chinese mentality]. General'nyi director [General Director]. Available at: http://www.gd.ru/articles/2819-red-kak-upravlyayut-personalom-v-kitae-osobennosti-kitayskogomentaliteta, accessed on 01.11.2017 (in Russian). 
Ng Y.C., Siu N.Y. (2004) Training and Enterprise Performance in Transition: Evidence from China. The International Journal of Human Resource Management, vol. 15, no 4-5, pp. 878-894.

Nyrova N.N. (2009) Podvodnye kamni upravleniya personalom v Kitae [Underwater Stones of Personnel Management in China]. Rossiiskii vneshneekonomicheskii vestnik [Russian Foreign Economic Journal], no 4, pp. 62-67 (in Russian).

OECD, Eurostat (2005) Oslo Manual. Guidelines for Collecting and Interpreting Innovation Data (3 ${ }^{\text {rd }}$ ed.), Paris: OECD, Eurostat.

Simon D., Cao C. (2009) Creating an Innovative Talent Pool. China Business Review. Available at: http://www. chinabusinessreview.com/creating-an-innovative-talent-pool/, accessed on 01.11.2017.

Soltitskaya T.A., Bo Z. (2005) Osobennosti sistemy upravleniya personalom v kitaiskikh kompaniyakh [The Personnel Management System in Modern China Companies]. Vestnik Sankt-Peterburgskogo universiteta. Seriya 8. Menedzhment [Vestnik of Saint Petersburg University. Management], no 2, pp. 90-104 (in Russian).

Sumelius J. (2009) Social networks and subsidiary HRM capabilities: The case of Nordic MNC subsidiaries in China. Personnel Review, vol. 38, no 4, pp. 380-397.

Tang S.F.Y., Lai E.W.K., Cheng L.Z., Zhang S.Q. (1996) Human Resource Management Strategies and Practices in Foreign Invested Enterprises in the PRC, Hong Kong: Hong Kong Institute of HRM.

Tsang E.W. (1994) Human resource management problems in Sino-foreign Joint Ventures. International Journal of Manpower, vol. 15, no 9, pp. 4-21.

Verburg R.M., Drenth P.J., Koopman P.L., Muijen J.J.V., Wang Z.M. (1999) Managing Human Resources across Cultures: A Comparative Analysis of Practices in Industrial Enterprises in China and the Netherlands. International Journal of Human Resource Management, vol. 10, no 3, pp. 391-410.

Warner M. (1993) Human Resource Management "with Chinese Characteristics". International Journal of Human Resource Management, vol. 4, no 1, pp. 45-65.

Warner M. (1996) Human Resources in the People's Republic of China: The “Three Systems" Reforms. Human Resource Management Journal, vol. 6, no 2, pp. 32-43.

Warner M. (2008) Reassessing Human Resource Management "with Chinese Characteristics": An Overview: Introduction. The International Journal of Human Resource Management, vol. 19, no 5, pp. 771-801.

Xinhua (2015) Innovative, small businesses get multibillion-dollar tax cuts in China. Available at: http://www. chinadaily.com.cn/business/2015-11/20/content_22487321.htm, accessed 01.11.2017.

Xie T. (2015) China, on its way to innovation. Available at: http://english.gov.cn/policies/policy_watch/2015/05/08/ content_281475103653822.htm, accessed on 01.11.2017.

Zhao S. (1994) Human Resource Management in China. Asia Pacific Journal of Human Resources, vol. 32, no 2, pp. 3-12.

Zhu C. J. (1998) Human Resource Development in China During the Transition to a New Economic System. Asia Pacific Journal of Human Resources, vol. 35, no 3, pp. 19-44. 